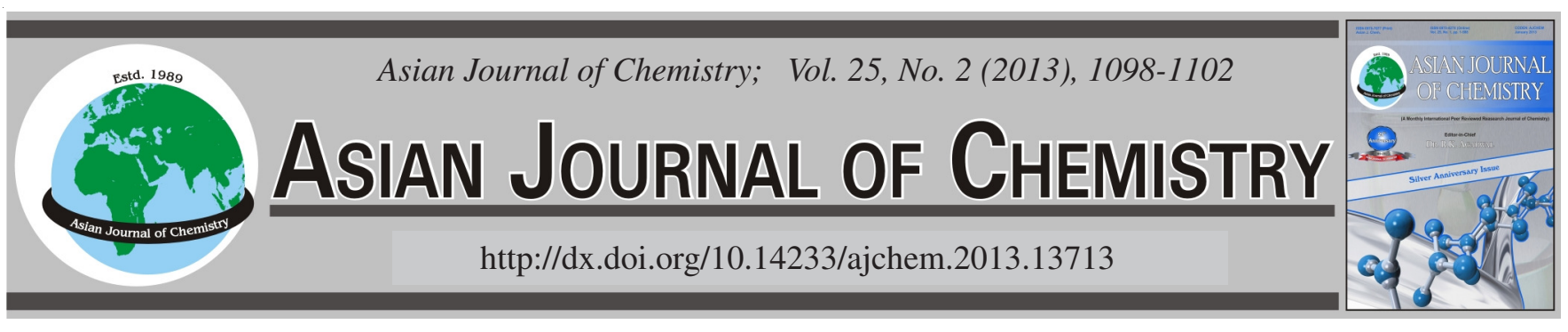

\title{
Effect of the Different COD/N Ratios on Multilevel Anaerobic/oxic Step-Feed Process for Integrated Removal of Carbon, Nitrogen and Phosphorus
}

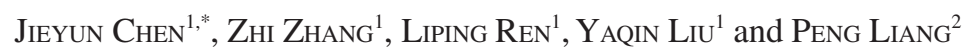

${ }^{1}$ Key Laboratory of Three Gorges Reservoir Region's Eco-Environment, Ministry of Education, Chongqing University, Chongqing 400045, P.R. China ${ }^{2}$ Building Design and Research Institute of the General Logistics Department of PLA, Beijing 100036, P.R. China

*Corresponding author: Tel: +86 25 65127191; E-mail: chenjieyun1004@ 126.com

(Received: 10 March 2012;

Accepted: 30 August 2012)

AJC-12052

The present object of this stuidy is to investigate the effect of the different $\mathrm{COD} / \mathrm{N}$ ratio on multilevel anaerobic/oxic $(\mathrm{A} / \mathrm{O})$ step-feed
process for nitrogen and phosphorus removal used actual life sewage. The experiment designed the fluctuation of influent $\mathrm{C} / \mathrm{N}$ ratio
ranging from 4 to 8 and studied the variation rules of $\mathrm{COD}, \mathrm{NH}_{3}-\mathrm{N}, \mathrm{NO}_{3}-\mathrm{N}, \mathrm{NO}_{2}-\mathrm{N}$, total nitrogen, total phosphorus in the multilevel
$\mathrm{A} / \mathrm{O}$ process. Results showed when the influent $\mathrm{C} / \mathrm{N}$ ratio was from 4 to 8 , the $\mathrm{C} / \mathrm{N}$ ratio on the removal efficiencies of $\mathrm{COD}$ and $\mathrm{NH} \mathrm{H}_{3}-\mathrm{N}$
was not significant, and $\mathrm{COD}$ average removal efficiency was $89.2 \%, \mathrm{NH}_{3}-\mathrm{N}$ average removal efficiency was $96.5 \%$. But the influent
$\mathrm{C} / \mathrm{N}$ ratio on denitrification and biological phosphorus removal effect was obvious, the total nitrogen removal rate increased from 44.7 to
68.9 to $87.3 \%$ when the influent $\mathrm{C} / \mathrm{N}$ ratio increased from 4 to 6 to 8 . In the absence of specialized set of anaerobic zone condition, the
total phosphorus removal efficiency had worked in certain. The total phosphorus removal rate increased from 58.7 to 64.7 to $71.8 \%$ when
the influent $\mathrm{C} / \mathrm{N}$ ratio increased from 4 to 6 to 8 . when the influent $\mathrm{C} / \mathrm{N}$ ratio was 8 , the effluent total phosphorus is $0.86 \mathrm{mg} / \mathrm{L}$.

Key Words: Multilevel A/O, C/N ratio, Step-feed influent, Nitrogen and phosphorus removal.
\end{abstract}

\section{INTRODUCTION}

In the conventional anaerobic/oxic $(\mathrm{A} / \mathrm{O})$ process, the biological nitrogen removal efficiency is in proportion to the activated sludge return ratio and when the activated sludge return ratio is raised, the biological nitrogen removal efficiency is also raised. In order to maintain a high nitrogen removal efficiency, it is necessary to increase the return sludge flow and nitrification liquid return flow, which can reach the purpose of improvement denitrification efficiency, thereby increasing daily energy consumption of the wastewater treatment plant and the dissolved oxygen which is brought by nitrification liquid back to the anoxic zone, thus affecting the denitrification efficiency ${ }^{1-3}$. In order to overcome the deficiencies of the conventional A/O process, some scholars have put forward a new idea of short-term anoxic/aerobic operation condition to replace the traditional single long anoxic and aerobic running, in which the influent flow is divided into several times, respectively, to enter anoxic zones ${ }^{4}$, carried out stage-aeration and rationally utilized carbon source, thus formed a multilevel A/O process. Extended research work on cascade nitrification-denitrification systems suggested high removal efficiencies and economically feasible unit configurations, when these systems are combined with the step feeding process. The multilevel A/O activated sludge system has the following advantages: the sewage enter into the system along the pool in the way of step-feed and the return sludge enter the head, solid residence time of the system is longer than that of the plug flow system in the same volume, so that the sludge age is increased, improve the ability of the reactor to adapt to the impact load on the quality and quantity; nitrification liquid from the aerobic zones directly flow into the next anoxic zones, which simplifies the process, helps to reduce energy consumption and also gives full play to the microbial degradation function of activated sludge ${ }^{5}$. There are some sewage operating units that transform the initial process to the multilevel A/O process and that achieves good results ${ }^{6}$, demonstrating the potential advantages of this process. However, the mechanism of multilevel $\mathrm{A} / \mathrm{O}$ process is still in the immature stage, its study mainly stay in the emulation process or the stage of simulation life sewage.

Nitrogen and phosphorus removal dependent on a large extent the type, quantity and quality of organic carbon source in wastewater. There is a common trait on southern urban sewage: a serious shortage of the carbon source, the influent $\mathrm{C} / \mathrm{N}$ ratio from 3 to 5 . It is generally believed that when $\mathrm{BOD}_{5} /$ total nitrogen $>4-6$, i.e. sewage $\mathrm{C} / \mathrm{N}$ ratio is up to 8 , the carbon source is sufficient. As to the low $\mathrm{C} / \mathrm{N}$ ratio sewage, the carbon source is the limiting factor of the denitrification and phosphorus 
release. Even if the carbon source in the raw water is taken full advantage of water, it cannot meet the emission standards of the effluent total nitrogen and total phosphorus ${ }^{7}$. The organic carbon source in the raw water is used maximum in the multilevel A/O process, especially for the low $\mathrm{C} / \mathrm{N}$ ratio urban life sewage. In this test, choose the urban sewage from the general sense and low-carbon sewage ( $\mathrm{C} / \mathrm{N}$ of from 4 to 8$)$ as the objects of studying the nitrogen and phosphorus removal, to provide operating parameters for the actual sewage treatment facilities and a theoretical basis for the sewage treatment plant upgrade by the analysis of the rules of the pollutants degradation along this process.

\section{EXPERIMENTAL}

Experimental set-up: Experimental equipment and multilevel A/O reactor structure are shown in Fig. 1. Multilevel $\mathrm{A} / \mathrm{O}$ reactor dimensions $(\mathrm{L} \times \mathrm{W} \times \mathrm{H})$ is: $720 \mathrm{~mm} \times 660 \mathrm{~mm} \times$ $1000 \mathrm{~mm}$, considering the ultra-high $30 \mathrm{~cm}$, the total working volume is $330 \mathrm{~L}$, transversely divided into three rectangular slots and the formation of three-level $\mathrm{A} / \mathrm{O}$ reactor, the volume of anoxic (A) zone and aerobic $(\mathrm{O})$ zone in each level can be adjusted by different partition locations. In this experiment, the volume ratio is 1:2 and use the stirring devices for mixing in the anoxic zone, sticky sand aeration head for aeration in the aerobic zone. The multilevel A/O reactor hydraulic retention time is $8 \mathrm{~h}$. The upper settling zone of vertical flow setting tank is the shape of cylinder and its diameter of $500 \mathrm{~mm}$, the sludge hopper is the shape of the truncated inverted cone, an inclination of $60^{\circ}$. The total height is $850 \mathrm{~mm}$ and the volume is $90 \mathrm{~L}$. The setting tank is worked in the way of the center tube influent, the surrounding triangular weir effluent. The return sludge is taken away by a peristaltic pump.

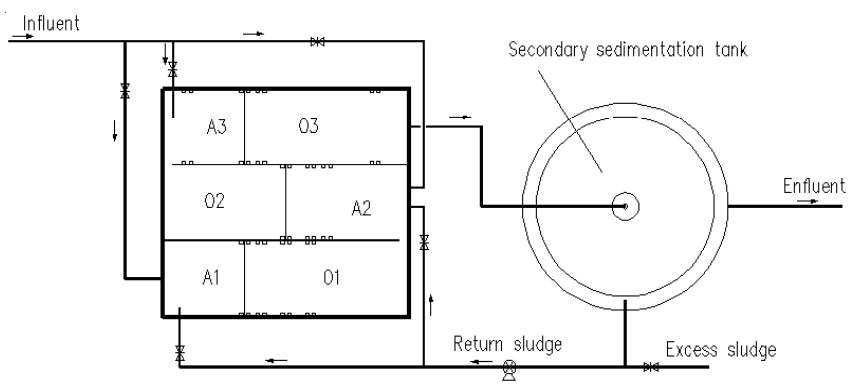

Fig. 1. Schematic diagram of multiple A/O reactor system

Water quality: The wastewater of the test is from the life sewage of Chongqing University B student dormitories. The wastewater was collected uniformly by the sewage pipes and imported into the reservoir out of the lab, filtered floating material and some large particle size of suspended solids by screen filters, then pumped into the high-position water tank by the lift pump. The influent was taken into the reactor after the high-position water tank. During the test, the range of the raw water was shown in Table-1. The influent quality of the test was according to the test requirement and the actual wastewater was poured into the appropriate amount anhydrous sodium in need of the test conditions.

Water sample testing and methods: In this test, COD is measured with potassium dichromate method; total nitrogen is measured with UV spectrophotometry. $\mathrm{NH}_{3}-\mathrm{N}$ is measured with Nessler's reagents spectrophotometer. $\mathrm{NO}_{3}-\mathrm{N}$ is measured with UV spectrophotometry; $\mathrm{NO}_{2}-\mathrm{N}$ is measured with $\mathrm{N}-(1-$ naphthyl)-ethylenediamine hydrochloride method. The content of dehydrogenase in activated sludge is measured with a maturer and stabler method-TTC method, the activity of dehydrogenize (DHA) is analyzed with the method in literature ${ }^{8}$.

Test operating scheme: Before starting the reactor, there was a water flow pattern test. Make sure the water was in the state of the plug flow by monitoring the rules of tracer $(\mathrm{NaCl})$ concentration variation and remolding partial the reactor, reducing the degree of back-mixing among various levels in the reactor with cutting down every level flow area. In the test, choose a 3-step influent pattern to study from the aspect of treatment efficiency and process simplicity, operational and other aspects. The critical parameters are that the volume ratio of anoxic zone and aerobic zone in each level of 1:2. The MLSS in the main reaction zone of $2000-2500 \mathrm{mg} / \mathrm{L}$ on average, in the progressively decreasing trend, the VSS/MLSS ratio of 0.75 ; the concentrations of dissolved oxygen $\mathrm{O} 1, \mathrm{O} 2$ and $\mathrm{O} 3$ are $0.2-0.4 \mathrm{mg} / \mathrm{L}, 0.4-0.6 \mathrm{mg} / \mathrm{L}$ and $1.0-1.5 \mathrm{mg} / \mathrm{L}$, respectively, controlled by the valve; the last level influent flow decrease appropriately, taking into consider that the influent in each level anoxic zone can provide denitrification carbon source which reduces the nitrate accumulation and be sure reaching the standards, so that the initial flow distribution ratio is $6: 3: 1$; test temperature is room temperature and the temperature is $18-25^{\circ} \mathrm{C}$; the hydraulic retention time (HRT) of the reactor is $8 \mathrm{~h}$. There are 3 operating conditions in the test, the $\mathrm{C} / \mathrm{N}$ ratio of 2:4:6, respectively; in each operating condition there was a $10 \mathrm{~d}$ sludge adaptation period and sample and monitor water quality, sludge characteristics index and the DO, ORP and $\mathrm{pH}$ value after stable operating.

\section{RESULTS AND DISCUSSION}

Effect of influent $\mathrm{C} / \mathrm{N}$ ratio on the organic removal efficiency: Fig. 2 showed that when the influent $\mathrm{C} / \mathrm{N}$ ratio ranges from 4 to 8 , i.e. COD is $135-280 \mathrm{mg} / \mathrm{L}$, the effluent COD is $15-25 \mathrm{mg} / \mathrm{L}$, an average of $c a .20 \mathrm{mg} / \mathrm{L}$, the COD removal rate keep steadily 85.2-94.6\%, an average of $c a$. $89.2 \%$. The effluent COD can meet the first level A criteria specified in the discharge standard of pollutants for municipal wastewater treatment plant (GB18918-2002) reliably. The composition of the effluent COD were non-biological degradation or difficult biodegradable material. As the sewage comes from campus, the water quality is somewhat simple, the difficult biodegradable material are little. The influent flow into each level anoxic zone and provide carbon source for denitrification

TABLE-1

WATER QUALITY OF INFLOW (mg/L)

\begin{tabular}{cccccc}
\hline Water quality objectives & $\mathrm{COD}$ & $\mathrm{NH}_{3}-\mathrm{N}$ & Total nitrogen & Total phosphorus & $\mathrm{pH}$ \\
\hline Range & $85-160$ & $28-34$ & $29-36$ & $1.8-3.9$ & $6.8-8.2$ \\
\hline
\end{tabular}




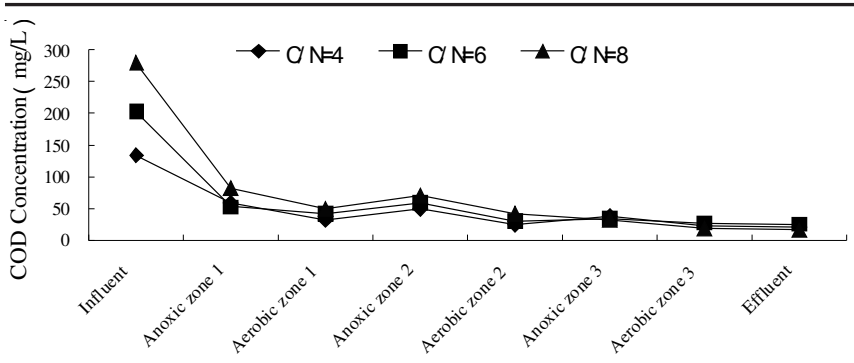

Fig. 2. Variation of $\mathrm{COD}$ along the reactor in different $\mathrm{C} / \mathrm{N}$ ratio condition

and most of organic material are used up for $\mathrm{NO}_{3}-\mathrm{N}$ from the aerobic zone before denitrification. Moreover, if there is the low concentration $\mathrm{NO}_{3}-\mathrm{N}$ and abundant carbon source in the latter of denitrification, phosphate accumulating bacteria would take advantage of this carbon source for anaerobic phosphorus release $\mathrm{e}^{9}$. The higher the $\mathrm{C} / \mathrm{N}$ ratio is, the higher the efficiency of carbon source of denitrifiers and phosphate accumulating bacteria is. The sewage re-entered into the aerobic zone for nitrification and the remaining carbon source was carbonization or simultaneous nitrification and denitrification to get a fuller use of the organic material of the aerobic zone.

\section{Effect of influent $\mathrm{C} / \mathrm{N}$ ratio on the removal nitrogen efficiency}

Effect of influent $\mathbf{C} / \mathrm{N}$ ratio on nitrification: Fig. 3 showed that the influent $\mathrm{NH}_{3}-\mathrm{N}$ concentration was 28.6-36.2 $\mathrm{mg} / \mathrm{L}$, the nitrogen load in the system was not high, the products were almost all of $\mathrm{NO}_{3}-\mathrm{N}$ during the nitrification stage, not found $\mathrm{NO}_{2}-\mathrm{N}$ accumulation by monitoring the water quality along the reactor. The effluent $\mathrm{NH}_{3}-\mathrm{N}$ concentration was $0.2-3.1 \mathrm{mg} / \mathrm{L}$, the removal rate remains at 93.0-99.4\%, i.e. the influent $\mathrm{C} / \mathrm{N}$ ratio has a little effect on $\mathrm{NH}_{3}-\mathrm{N}$ removal efficiency. According to the analysis, the influent entered into each anoxic zone in proportion, carbon source was utilized in the anoxic zones by denitrifiers and then entered into the aerobic zones, making sure the aerobic zone keep the low nutritional state and the low COD load, denitrifiers (heterotrophic bacteria) are limited because of no or little carbon source utilization $^{10}$, resulting in the endogenous consumption stage in the aerobic zone. Nitrifies are of self-care type, utilize $\mathrm{O}_{2}$, consume the alkalinity in sewage and implement nitrify effect. These nitrifies are in a dominant position in the competition of heterotrophic bacteria, transforming steadily $\mathrm{NH}_{3}-\mathrm{N}$ to $\mathrm{NO}_{3}-\mathrm{N}$. When the influent $\mathrm{C} / \mathrm{N}$ ratio was over 6 , the result showed the effluent $\mathrm{NH}_{3}-\mathrm{N}$ concentration was so low that it was hard to find. It was feasible to cut down the volume of the aerobic zone to control the effluent $\mathrm{NH}_{3}-\mathrm{N}$ concentration and save the aeration amount and power consumption. At the same time, by the test of measurement nitrification rate, the nitrification rate is 0.13 $0.15 \mathrm{~kg} \mathrm{NH}_{3}-\mathrm{N} /(\mathrm{kgMLVSS} \mathrm{d})$ in the aerobic zone, but the

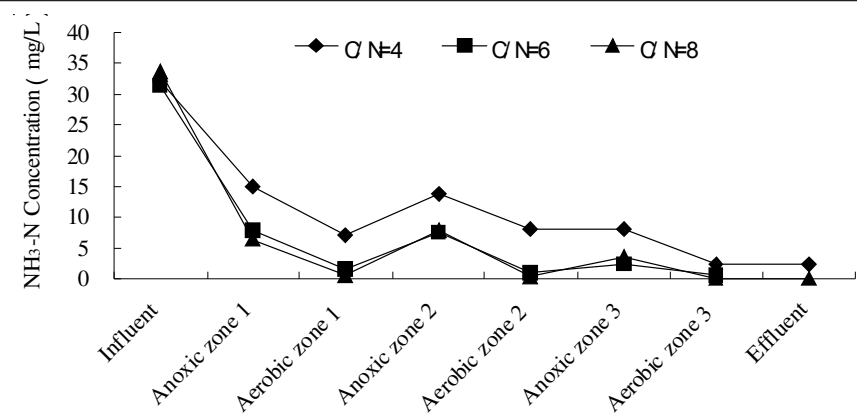

Fig. 3. Variation of $\mathrm{NH}_{3}-\mathrm{N}$ along the reactor in different $\mathrm{C} / \mathrm{N}$ ratio condition

ammonia nitrogen load of the system is $0.09-0.11 \mathrm{~kg} \mathrm{NH}_{3}-\mathrm{N} /$ ( $\mathrm{kg}$ MLVSS d), that is to say that nitrification capacity is to meet nitrification demand. Good nitrification can guarantee to provide adequate electron acceptor for denitrification and avoid the waste of carbon source.

Effect of influent $\mathrm{C} / \mathrm{N}$ ratio on denitrification: From Fig. 4, the anoxic zone, aerobic zone $\mathrm{NO}_{3}-\mathrm{N}$ concentration gradually increased by the levels, in every level, the $\mathrm{NO}_{3}-\mathrm{N}$ concentration in the anoxic zone was lower than that in the aerobic zone. The denitrifying bacteria deoxygenized $\mathrm{NO}_{3}-\mathrm{N}$ in the anoxic condition into nitrogen gas $\left(\mathrm{N}_{2}\right)$ and released into the air to reach the purpose of denitrification. Under various $\mathrm{C} / \mathrm{N}$ ratios, the denitrification efficiency was the highest and the $\mathrm{NO}_{3}-\mathrm{N}$ concentration was the lowest in the first level anoxic zone. With the increasing the $\mathrm{C} / \mathrm{N}$ ratio, the $\mathrm{NO}_{3}-\mathrm{N}$ concentration of all levels was decreased. When carbon source was sufficient ( $\mathrm{C} / \mathrm{N}$ of 8$)$, it approached to the complete denitrification in the first anoxic zone, denitrification rate of $91.1 \%$ and the $\mathrm{NO}_{3}-\mathrm{N}$ concentration was increased cumulatively in the last two levels. The specific date can be seen from the nitrogen material balance in Table-2. At a certain $\mathrm{C} / \mathrm{N}$ ratio, the nitrification and denitrification capacity has been enhanced with the $\mathrm{C} / \mathrm{N}$ ratio increased. The ammonia removal efficiencies at the aerobic zones of all levels were relatively stable, but the denitrification efficiencies were progressively decreasing and the amount of $\mathrm{NO}_{3}-\mathrm{N}$ was gradually accumulated, which was associated with the sludge concentration decreasing and HRT shortage at the latter two levels anoxic zones by the analysis. Nitrification produced $\mathrm{NO}_{3}-\mathrm{N}$ which would enter into the next level anoxic zone was much more than the denitrification capacity, resulting to an incomplete denitrification. By monitoring dehydrogenize activity (DHA) of all levels, the results also showed that DHA was progressively decreasing from 12 $\mu \mathrm{g} / \mathrm{mg}$ h to $6 \mu \mathrm{g} / \mathrm{mg} \mathrm{h}$, indicating that microbial activity was also progressively decreasing. The test results were according with the rule that the decreasing of the microbe biochemical activity was the response to the decreasing of the substrate concentration in the reaction progress.

\begin{tabular}{|c|c|c|c|c|c|c|c|}
\hline \multicolumn{8}{|c|}{$\begin{array}{c}\text { TABLE-2 } \\
\text { REMOVAL RATE OF } \mathrm{NH}_{3}-\mathrm{N} \text { IN AEROBIC ZONES AND NO} \text { N }_{3} \mathrm{~N} \text { IN ANOXIC ZONES }\end{array}$} \\
\hline $\mathrm{C} / \mathrm{N}$ & $\begin{array}{l}\mathrm{NO}_{3}-\mathrm{N} \text { removal } \\
\text { rate in anoxic } \\
\text { zone } 1(\%)\end{array}$ & $\begin{array}{l}\mathrm{NH}_{3}-\mathrm{N} \text { removal } \\
\text { rate in aerobic } \\
\text { zone } 1(\%)\end{array}$ & $\begin{array}{c}\mathrm{NO}_{3}-\mathrm{N} \text { removal } \\
\text { rate in anoxic } \\
\text { zone } 2(\%)\end{array}$ & $\begin{array}{l}\mathrm{NH}_{3}-\mathrm{N} \text { removal } \\
\text { rate in aerobic } \\
\text { zone } 2(\%)\end{array}$ & $\begin{array}{c}\mathrm{NO}_{3}-\mathrm{N} \text { removal } \\
\text { rate in anoxic } \\
\text { zone } 3(\%)\end{array}$ & $\begin{array}{l}\mathrm{NH}_{3}-\mathrm{N} \text { removal } \\
\text { rate in aerobic } \\
\text { zone } 3(\%)\end{array}$ & $\begin{array}{l}\text { Total nitrogen } \\
\text { removal rate in } \\
\text { system }(\%)\end{array}$ \\
\hline 4 & 26.6 & 53.7 & 12.8 & 42.4 & 7.7 & 72.4 & 44.7 \\
\hline 6 & 48.0 & 82.0 & 32.3 & 88.9 & 10.2 & 87.5 & 68.9 \\
\hline 8 & 91.1 & 91.3 & 45.9 & 96.4 & 39.3 & 97.2 & 84.8 \\
\hline
\end{tabular}




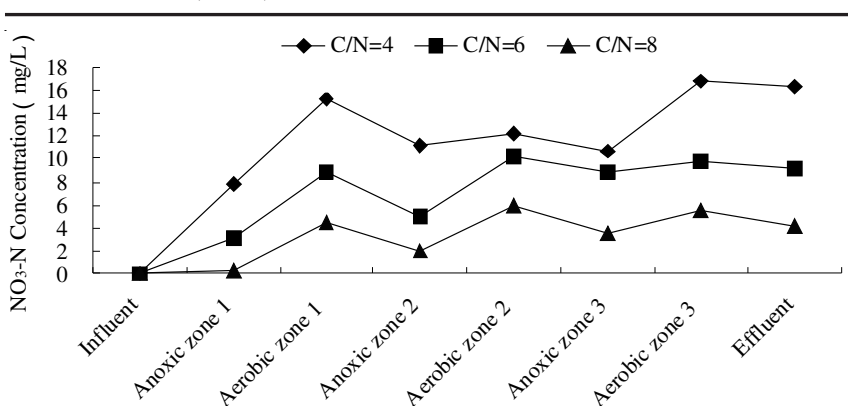

Fig. 4. Variation of $\mathrm{NO}_{3}-\mathrm{N}$ along the reactor in different $\mathrm{C} / \mathrm{N}$ ratio condition

Effect of influent $\mathrm{C} / \mathrm{N}$ ratio on the removal efficiency of total nitrogen: The removal of total nitrogen is completed by the nitrification and denitrification of the microbe, in which denitrification is the major way of final removal and denitrification of nitrogen is generally carried out in anoxic conditions. When the influent total nitrogen concentration is certain, the increasing of the influent organic concentration contributes to denitrification process. Therefore, with increasing $\mathrm{C} / \mathrm{N}$ ratio, the effluent total nitrogen concentration decreased ${ }^{11,12}$. In the conditions of different $\mathrm{C} / \mathrm{N}$ ratio, total nitrogen removal effect shown in Fig. 5 in the multilevel A/O process. When the C/N ratio was $c a$. 4, total nitrogen removal rate of the reactor was just $44.7 \%$, the effluent total nitrogen was $18.7 \mathrm{mg} / \mathrm{L}$. With increasing $\mathrm{C} / \mathrm{N}$ ratio, the total nitrogen removal rate would be improved. When the $\mathrm{C} / \mathrm{N}$ ratio was about 6 , total nitrogen removal rate of the reactor was about $68.9 \%$, the effluent total nitrogen was $10.2 \mathrm{mg} / \mathrm{L}$, meeting the first A standard. When the $\mathrm{C} / \mathrm{N}$ ratio rose further, the increasing of total nitrogen removal rate was limited. When the $\mathrm{C} / \mathrm{N}$ ratio was about 8 , total nitrogen removal rate of the reactor was up $84.8 \%$, the effluent total nitrogen was just $5.7 \mathrm{mg} / \mathrm{L}$. It was noticeable when $\mathrm{C} / \mathrm{N}$ was low, the carbon source in denitrification process was not enough and then decreased obviously total nitrogen removal rate. But compared with the pre-denitrification process, if reaching total nitrogen removal rate of $84.8 \%$, it was necessary to keep the nitrification liquid reflux ratio of $460 \%$ in addition to the external reflux ratio of $100 \%$, so the save-energy advantage in step-feed influent process was illustrated.

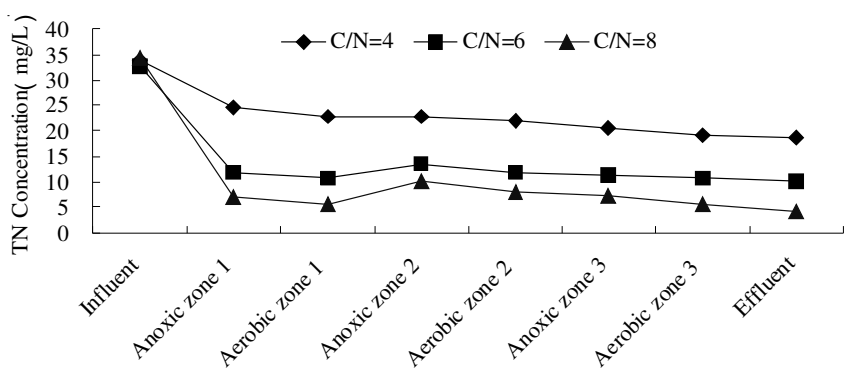

Fig. 5. Variation of total nitrogen in different $\mathrm{C} / \mathrm{N}$ ratio condition

Fig. 5 showed that there was a phenomenon of nitrogen loss in the aerobic zone. In the aerobic zone, the ammonia nitrogen reduction was significantly greater than the nitrate increasing. According to the analysis, there was simultaneous nitrification and denitrification (SND). In recent years, study shows that the low DO concentration is conducive to simultaneous nitrification and denitrification, greatly enhances the treatment effect and reduces the volume of the pool ${ }^{13,14}$. There- fore, it was the focus of the advanced nitrogen removal in the multilevel A/O process to strengthen simultaneous nitrification and denitrification effect to the maximum extent under the condition of certain nitrification effect.

Effect of influent $\mathrm{C} / \mathrm{N}$ ratio on total phosphorus removal efficiency: It can be seen from Fig. 6 that there was a certain phosphorus removal in the operating process, even though in number of specialized anaerobic zone. When the $\mathrm{C} / \mathrm{N}$ ratio was $4,6,8$, the influent phosphorus concentration was 2.98 $\mathrm{mg} / \mathrm{L}, 3.12 \mathrm{mg} / \mathrm{L}, 3.05 \mathrm{mg} / \mathrm{L}$, respectively, the effluent phosphorus concentration was $1.23 \mathrm{mg} / \mathrm{L}, 1.10 \mathrm{mg} / \mathrm{L}, 0.86 \mathrm{mg} / \mathrm{L}$ and the removal ratio was $58.7 \%, 64.7 \%, 71.8 \%$, respectively. Total phosphorus concentrations of the anoxic zones were significantly higher than that of the aerobic zones, illustrating there was phosphorus release in some extent in anoxic zones and this effect was more obvious with increasing of the carbon source. The reasons of the phenomenon were as followed: if there was a low $\mathrm{NO}_{3}-\mathrm{N}$ concentration and an affluence carbon source in the latter denitrification of the anoxic zones, there is the low concentration $\mathrm{NO}_{3}-\mathrm{N}$ and abundant carbon source in the latter of denitrification, phosphate accumulating bacteria would take advantage of this carbon source for anaerobic phosphorus release taken advantage of this carbon source for phosphorus release in the anaerobic condition. The higher the total nitrogen removal rate was, the lower the effluent $\mathrm{NO}_{3}-\mathrm{N}$ concentration was, which weakened the impact of anaerobic phosphorus release at the beginning of next cycle to some extent, thus contributing to phosphorus removal. Then when the sewage entered into the aerobic zone, there is the low concentration $\mathrm{NO}_{3}-\mathrm{N}$ and abundant carbon source in the latter of denitrification, phosphate accumulating bacteria would take advantage of this carbon source for anaerobic phosphorus release oxidize PHB which was stored in cells, excessively intake phosphate from sewage and transform polyphosphate, as energy stored in cells, then removed phosphorus by the emission of the sludge ${ }^{15}$. Therefore, when HRT was constant, adjust to the operating conditions; maintain the low $\mathrm{NO}_{3}-\mathrm{N}$ concentration in the return sludge and then form an anaerobic surrounding in the late anoxic zones to improve phosphorus removal efficiency.

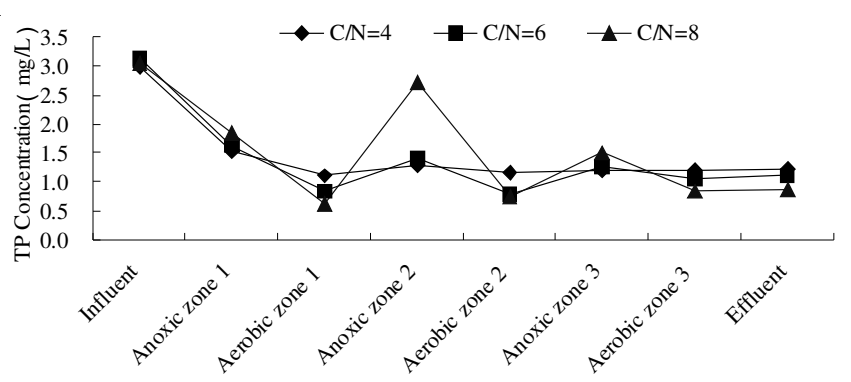

Fig. 6. Variation of total phosphorus in different $\mathrm{C} / \mathrm{N}$ ratio condition

\section{Conclusion}

When the influent $\mathrm{C} / \mathrm{N}$ ratio was from 4 to $8, \mathrm{COD}$ and $\mathrm{NH}_{3}-\mathrm{N}$ removal efficiencies in the multilevel $\mathrm{A} / \mathrm{O}$ process were stable, the effluent quality can meet the first level A standard. When the influent $\mathrm{C} / \mathrm{N}$ ratio was over 6 , it was feasible to cut down the volume of the aerobic zone to control the effluent $\mathrm{NH}_{3}-\mathrm{N}$ concentration and save the aeration amount and power 
consumption. The step-feed pattern makes full use of carbon source and the denitrification capacity increased with the increasing of $\mathrm{C} / \mathrm{N}$ ratio. When $\mathrm{C} / \mathrm{N}$ ratio was $4,6,8$, total nitrogen removal rate was $44.7,68.9$ and $87.3 \%$, respectively. A phenomenon of nitrogen loss in the aerobic zone revealed simultaneous nitrification and denitrification. Therefore, it was the focus of the advanced nitrogen removal in the multilevel $\mathrm{A} / \mathrm{O}$ process to strengthen simultaneous nitrification and denitrification effect to the maximum extent under the condition of certain nitrification effect. Phosphate accumulating bacteria would take advantage of this carbon source for anaerobic phosphorus release when low concentration $\mathrm{NO}_{3}-\mathrm{N}$ and abundant carbon source in the latter of denitrification, which enhanced the phosphorus efficiency. When $\mathrm{C} / \mathrm{N}$ ratio was $c a$. 8 , the total phosphorus of effluent was $0.86 \mathrm{mg} / \mathrm{L}$ which met the demanded A of integrated wastewater discharge standards (GB 18918-2002).

\section{ACKNOWLEDGEMENTS}

This work was financially supported by National Key Science and Technology Special Projects (2009ZX07315-002) and Project No. CDJXS12 210003 Supported by the Fundamental Research Funds for the Central Universities.

\section{REFERENCES}

1. Z.M. Fu, F.L. Yang, F.F. Zhou and Y. Xue, Bioresour. Technol., 100, 136 (2009).

2. S.M. Souza, O.Q.F. Araújo and M.A.Z. Coelho, Bioresour. Technol., 99, 3213 (2008).

3. A. Oehmen, P.C. Lemos, G. Carvalho, Z.G. Yuan, J. Keller, L.L. Blackall and M.A.M. Reis, Water Res., 41, 2271 (2007).

4. N. Hvala, M. Zec, M. Ros and S. Strmcnik, Water Environ. Res., 73, 146 (2001).

5. L. Larrea, A. Larrea, E. Ayesa, J. Rodrigo, M. Lopez-Carrasco and J. Cortacans, Water Sci. Technol., 43, 261 (2001).

6. W. Saktaywin, H. Tsuno, H. Nagare and T. Soyama, Water Sci. Technol., 53, 217 (2006).

7. C. deBarbadillo, L. Carrio, K. Mahoney, J. Anderson, N. Passarelli, F. Streett and K. Abraham, Florida Water Resour. J., 1, 18 (2002).

8. R.H. Nielsen, Water Res., 9, 1179 (1975)

9. S.A. Beril, Bioresour. Technol., 94, 1 (2004).

10. L. Michaud, J.P. Blancheton and I.V. Brun, Aquacult. Eng., 34, 324 (2006).

11. G.G. Sun and D. Austin, Chemosphere, 68, 1120 (2007)

12. M. Fuerhacker, H. Baver, R. Ellinger, U. Sree, H. Schmid, F. Zibuschka and H. Puxbaum, Water Res., 34, 2499 (2000).

13. K.A. Third, N. Burnett and C.C. Ruwisch, Biotechnol. Bioeng., 83, 706 (2003)

14. K. Pochana and J. Keller, Water Sci. Technol., 39, 61 (1999).

15. J. Nivala, M.B. Hoos, C.S. Cross, S.D. Wallace and G.F. Parkin, Sci. Total Environ., 380, 19 (2007). 